\title{
Estrogen Receptor Agonist GTx-758
}

National Cancer Institute

\section{Source}

National Cancer Institute. Estrogen Receptor Agonist GTX-758. NCI Thesaurus. Code C96432.

An orally available, nonsteroidal selective estrogen receptor (ER) alpha agonist with potential antineoplastic activity. Upon administration of GTX-758, this agent suppresses the secretion of the gonadotropins follicle-stimulating hormone (FSH) and luteinizing hormone (LH) by the pituitary gland through feedback inhibition. In males, the inhibition of LH secretion prevents the synthesis of androgens, including testosterone, by the testes. This may result in suppressed total serum testosterone to the levels observed in castration. 